\title{
Competency Needs of Industry 4.0 Companies
}

\author{
Bogusław Plawgo ${ }^{1}$, Agnieszka Ertman²
}

Submitted: 1.03.2020. Accepted: 14.09.2021

\section{Abstract}

Purpose: The main aim of the study is the analysis of the awareness of competency needs in businesses in relation to the development of Industry 4.0 and the possibility of meeting those needs within business cooperation networks.

Methodology: We formed a model of competency needs for companies operating as part of Industry 4.0 in Poland, considering the needs of managers and other staff members. The model was then employed in empirical studies. The pilot empirical study was conducted using two methods: a quantitative CAWI method, which covered 81 companies from the metal processing and machine industry in Podlaskie Voivodship, and a qualitative IDI on a sample of 25 organizations.

Findings: Manufacturing companies are not fully aware of the competency needs related to Industry 4.0, covered by the established model. Moreover, we found that the most strongly felt competency needs - both by managers and other employees - may not be met within the business cooperation network. In order to satisfy these needs, partners must be found outside the studied network. The business cooperation network that we studied may only satisfy the less noticeable competency needs.

Implications: The developed competency model should be studied and further verified, including testing with a larger sample of companies, specifying the behavioral competency gaps related to Industry 4.0, their filling in using formal education systems, lifelong education, internships, and apprenticeships. The need for further research is dictated by the intensity of processes occurring within the Fourth Industrial Revolution.

Value: The pilot nature of the study and its limited sample do not undermine its contribution to the body of knowledge as it confirms that the competencies of managers and other staff members are one of the key determinants of successful implementation of the Industry 4.0 concept in Poland.

Keywords: Fourth Industrial Revolution, Industry 4.0, competency, manufacturing.

JEL: D8, J24, 03

\footnotetext{
Management Institute, University of Bialystok, ul. Warszawska 63, 15-062 Bialystok, Poland; e-mail: bplawg0@uwb.edu.pl; https://orcid. org/0000-0003-2521-3929.

2 Faculty of Economics and Finance, University of Bialystok, ul. Warszawska 63, 15-062 Bialystok, Poland; e-mail: a.ertman@uwb.edu.pl; https://orcid.org/0000-0001-9083-8007.
} 


\section{Introduction}

Digital transformation, otherwise known as the Fourth Industrial Revolution (4IR), is one of the three mega-trends observed in modern industry, leading to organizational changes, which introduce digital technologies to all aspects of business operations. Digital transformation comprises of such main subtrends as (Innogy Polska, 2019):

- increase in the importance of data processing through the use of large datasets (big data) for the development and optimization of business processes;

- introduction of autonomous machines, using machine learning technology to perform non-routine functions;

- adapting labor to the new requirements of the digital world by e.g. strengthening human capital in the coming age of machines.

Therefore, we should realize that Industry 4.0 means not only technologies but also new approaches to work and other expectations from people employed in industry. It is uncertain whether digital transformation would lead to reduced employment, but it will surely increase the efficiency of people, machines, and processes. Automation and robotics in manufacturing are unlikely to eliminate the human element but will nevertheless change their place in the production process. Industry 4.0 will only come to be with the support of new technologies and human creativity. We may safely assume that ideal Industry 4.0 employees are interdisciplinary, quickly adapting to change, communicative, and presenting a "win-win" attitude (Nosalska et al., 2019).

This article builds on the famous phrase by Jack Welch that "getting the right people in the right jobs is a lot more important than developing a strategy" (Welch and Byrne, 2003). These words are not outdated in the era of digital revolution. We may even say that employees - and essentially their competencies - will remain the core pillars of each company, determining its competitive edge. However, we cannot ignore the fact that expectations regarding employees are also changing, and more importantly, this process will only become more pronounced with the unfolding technological revolution. It is in this context that this article scrutinizes the specific competency needs resulting from the development of Industry 4.0 in Poland.

This article seeks to analyze the awareness of competency needs in businesses in relation to the development of Industry 4.0 and the possibility of meeting those needs in business cooperation networks. This objective stems from the assumption that the effective implementation of the 4IR may encounter a barrier in Poland in the form of the maladjustment of competencies offered by employees and managers. The article 
indicates that the 4IR requires from employees new and specific competencies, which they currently do not possess. Thus, we formulated two key research questions: (1) Are competency needs regarding Industry 4.0 noticed by manufacturing companies? And (2) can such needs be possibly satisfied within cooperation networks? This leads us to two corresponding hypotheses. The first hypothesis is that manufacturing companies are unaware of all competency needs related to Industry 4.0. The second hypothesis is that competency needs may be satisfied in a network, e.g. a business cooperation network.

The above research questions follow Armstrong's and Taylor's approach, which identifies three types of competencies: NVQs/SNVQs, technical competencies, and behavioral competencies (Armstrong and Taylor, 2014). We should emphasize that previous research conducted focused on the competencies called "hard skills" (technical) and professional qualifications (NVQs/SNVQs). Meanwhile, the impact of 4IR on changes in "soft skills" (behavioral competencies) has not been sufficiently explored, thus creating a research gap.

The paper is organized as follows: part one will review the subject literature, which overviews the discussion on competency and how it relates to the idea of Industry 4.0. Moreover, the part will analyze current results regarding the specificity of competency needs that ensue from the development of Economy 4.0. Next, the article will formulate a model of competency needs for companies operating as part of Industry 4.0 in Poland, including the needs of managers and employees. The methodology part of the paper will raise two research questions and formulate corresponding hypotheses, together with an analysis of the research methodology and the studied sample. The final part will present the results of research and hypotheses verification.

\section{Literature Review}

Competencies are a multidimensional concept, which makes their definition all the more difficult. One of the first people to write about competency was McClelland, who indicated that competency is precisely what determines professional success, not personality or intelligence, as many believed earlier (McClelland, 1973). This idea was further developed by Boyatzis, whose work focused on finding the qualities that define an effective manager. He determined that competency combines such elements as personality traits, motivation, skills, self-image, and social role. Adequate competency contributes to performing professional tasks in a way that satisfies requirements of a job (Boyatzis, 1982). In his pioneering publication, Boyatzis claims that competency is one of the key factors that determine employee work efficiency. He discerns threshold 
competencies necessary to perform certain work and competencies related to actions that allow us to differentiate high efficiency from low efficiency (differentiating competencies). In his text, Boyatzis claims that there is no single factor that determines whether an organization is successful, instead arguing for a set of factors that condition a company's economic success or failure. Employee characteristics - especially their motivation, professional experience, and behavioral traits - have a prominent place among Boyatzis' factors. Acknowledging the personal qualities of employees as a determining factor of an organization's success was a response to the organizational changes and various changes in society (Boyatzis, 1982).

Since then, numerous authors attempted to define competency (Armstrong, 2002; Gick and Tarczyńska, 1999; Król and Ludwiczyński, 2014). Dubois and Rothwell describe competency as not only knowledge and skills but also personality traits, thus agreeing with the earlier definition, which states that employees use their competencies to effectively complete units of work or job tasks (Dubois and Rothwell, 2008).

Polish authors also try to define competencies. Borkowska describes competencies as behavior determined by knowledge, skills, motivation, and attitudes of employees, which differentiate them in specific professional situations. Learning the competencies of employees is to allow us to predict their behavior in new situations (Borkowska, 2001). The definition prepared by Sajkiewicz includes personality traits and operational styles (Sajkiewicz, 2002), although Filipowicz indicates that these elements remain the same and are not freely shaped or developed, therefore disagree with the most important feature of competencies: their changeability (Filipowicz, 2016).

Also contemporary analyses of challenges connected to the implementation of Industry 4.0 highlight the role of competencies. Imran and Kantola review challenges related to the concept of Industry 4.0 and the basic requirements for its successful implementation. They propose that an approach based on competency as one of the best approaches towards the implementation of Industry 4.0 in organizations (Irman and Kantola, 2019). Nevertheless, other researchers believe that inadequate competencies can become an important barrier to the implementation of Industry 4.0 (Halse and Jaeger, 2019).

At the same time, we should emphasize that the importance of competencies in the implementation of Industry 4.0 is relatively poorly studied in the literature. The problem of competencies is not included in studies related to the implementation challenges of Industry 4.0. Notably, the subject of competencies remains underestimated in an analysis of Industry 4.0's determinants by Wichmann, Eisenbart, and Gericke (2019). 
Defining competencies for Industry 4.0 requires a universal understanding of what they are, namely "features in terms of knowledge, skills, and attitudes which make it possible to perform job tasks at a satisfactory level” (Filipowicz, 2016). That is why competencies for Industry 4.0 combine knowledge, skills, and attitudes recognized as necessary for company operations during the unfolding 4IR. To establish a more detailed model of competency needs in Industry 4.0, we should consider the definition proposed by Armstrong and Taylor who note that "the term competency refers to an underlying characteristic of a person that results in effective or superior performance" (Armstrong and Taylor, 2014).

Figure 1. Competency types according to Armstrong and Taylor

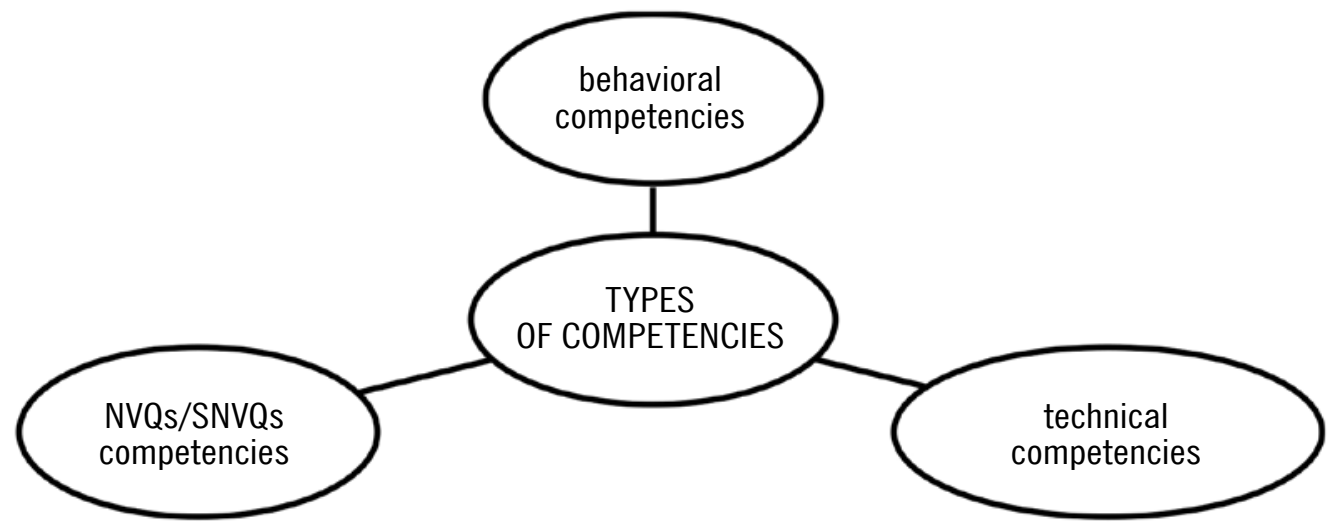

Source: own elaboration of Armstrong and Taylor (2014).

Armstrong and Taylor indicate that there are three types of competencies, as illustrated in Figure 1. Behavioral competencies determine behavior in terms of teamwork, communication, leadership, and decision-making, namely soft skills. Technical competencies are the knowledge in a specific field that employees should have, along with the ability to use it in practice to meet their efficiency expectations. Such competencies are occasionally called hard skills and pertain to tasks performed in specific fields of work or environments. National Vocational Qualifications (NVQs) and Scottish National Vocational Qualifications (SNVQs) refer to specific legal frameworks of particular countries, which can be defined as formally recognized professional qualifications. These are work-related competency-based qualifications that reflect the skills and knowledge needed to do a specific job.

With Armstrong's model in mind, let us consider the results of studies on competency needs related to the implementation of Industry 4.0. However, we know not which 
competency needs are experienced most strongly: the soft competencies, the hard competencies, or the formal vocational qualifications in specific sectors.

The studies conducted so far on competency challenges related to Industry 4.0 focused on two types of competencies. Some researchers were interested in the obsolescence of professional qualifications and the need for changes in the education system. Tùtlys and Spöttl (2021) reveal the implications of 4IR for vocational and professional qualifications, along with the system of forming such qualifications. For instance, they argue that engineering education must change. The demands of Industry 4.0 are reshaping the working world of future engineers. Therefore, it is very likely that these technological developments will soon affect higher education institutions with increasing intensity (Terkowsky, Frye, and May, 2019).

The research on higher education revealed the demand for a diverse mix of competencies in the current and prospective Industry 4.0 environment. Future employers will likely highlight multidisciplinary skills that may be categorized into three crucial groups: social, personal, and methodological (Rawboon et al., 2021). Similar conclusions about the existence of competency gaps referring to both technical competencies and soft skills in higher education appear in other studies conducted in developing countries, for example in Romania (Dumitrescu et al., 2019). Moreover, studies notice a growing need for changes in secondary vocational education (Made Sudana, Apriyani, and Nurmasitah, 2019).

Past literature includes numerous studies that document the implications of 4IR for hard skills. Most often, such skills are simply combined with digital competencies. The studies conclude that hard skills should also gain more prominence in the higher education system because their shortage makes employees struggle in adapting to the labor market (Khan et al., 2021). Consequently, what also must change is the education system, especially for specialists related to technology. The unfolding 4IR causes companies to need technicians and workers with digital skills, and those who have abilities and competencies in the Industry 4.0 Key Enabling Technologies (KET). In the UK, for instance, the lack of digital skills is considered perhaps the most serious obstacle to the practical implementation and investment in manufacturing digitalization technologies (Azmat et al., 2020). In the relatively extensive literature on the competency needs of Industry 4.0, there is a common opinion underlying the necessity of hard competencies, such as the ability to use and interact with Industry 4.0 technologies, data analysis, technical knowledge (Hernandez-de-Menendez et al., 2020). 
Regardless of the above reports, we may agree that Industry 4.0 research is mostly concerned with its technological and organizational challenges, while "existing models are mostly early-stage proposals addressing competencies featured in mainstream 21-century and digital-competency frameworks" (Blayone and Van Oostveen, 2021). The importance of soft skills has been poorly emphasized in the literature so far. Certain conclusions about the importance of soft skills appeared in studies on managers, like the analysis of the role of human resources (HR) professionals in navigating Industry 4.0 (Dhanpat et al., 2020). Similarly, the analysis of competency needs concerning project managers showed the existence of more behavioral or soft skills associated with the 4.0 project manager profile compared to the traditional project manager profile (Ribeiroa, Amaralb, and Barrosb, 2021). However, we should stress that the above studies concern the needs of various types of managers but not executive employees. The lack of studies on soft skills among non-managers is particularly noticeable. This research gap refers to the impact of 4IR on competency needs in behavioral competencies. This study seeks to fill the gap.

A good place to start the evaluation of the importance of different types of competencies in the face of $4 \mathrm{IR}$ - with a special focus on soft skills - is the literature review of international studies by consulting agencies.

The significance of connecting modern technologies with unique personal qualities was recognized by the CEOs surveyed by $\mathrm{PwC}$ in 2017. Coming from 79 countries, 1379 CEOs participated in the survey, indicating the importance of skills and attitudes which still cannot be provided by machines. At the same time, such skills and attitudes are necessary to stimulate innovation. PwC's report shows that the CEOs have difficulty finding employees who possess skills such as creativity, innovation, leadership, emotional intelligence, adaptability, and problem-solving abilities, although the last two traits are crucial from the perspective of their organizations (PwC, 2017). This shows that the study indicated the importance of the soft competencies that must accompany technological transformation (Table 1).

The authors of the report Preparing tomorrow's workforce for the Fourth Industrial Revolution For business: A framework for action, prepared for Deloitte (2018), found that millions of young people around the world are unemployed or underemployed, while employers have job positions they cannot fill. This situation results from a mismatch between employee skills and employer needs. The report also states that the problem will become even more pronounced with the unfolding 4IR, and the authors list the skills needed for 4IR. These skills are divided into four categories, characterized by examples and methods for developing them further (see Table 2). 
Table 1. Skills CEOs want to find in employees

\begin{tabular}{|l|c|c|}
\hline \multicolumn{1}{|c|}{ Skill } & $\begin{array}{c}\text { How difficult, if at all, is it for your } \\
\text { organisation to recruit people with } \\
\text { these skills or characteristics?* }\end{array}$ & $\begin{array}{c}\text { How important are the } \\
\text { following skills to your } \\
\text { organisation?** }\end{array}$ \\
\hline Creativity and innovation & $77 \%$ & 5 \\
\hline Leadership & $75 \%$ & 4 \\
\hline Emotional intelligence & $64 \%$ & 6 \\
\hline Adaptability & $61 \%$ & 2 \\
\hline Problem solving & $61 \%$ & 1 \\
\hline
\end{tabular}

Note: * respondents who answered somewhat difficult or very difficult; ** respondents who answered somewhat important or very important.

Source: own elaboration of PwC (2017).

Table 2. Skills required for 4IR by Deloitte

\begin{tabular}{|c|c|c|}
\hline Skill categories & Examples & $\begin{array}{l}\text { Teaching/ } \\
\text { training } \\
\text { methodology }\end{array}$ \\
\hline $\begin{array}{l}\text { Workforce } \\
\text { Readiness }\end{array}$ & $\begin{array}{l}\text { Literacy, numeracy, digital literacy, resume writing, } \\
\text { self-presentation, time management, professionalism, } \\
\text { etiquette, social norms }\end{array}$ & \multirow{4}{*}{$\begin{array}{l}\text { - Team-based } \\
\text { - Project-based } \\
\text { - Practical } \\
\text { - application } \\
\text { - Experiential } \\
\text { - Case simulation } \\
\text { - Business } \\
\text { - exposure } \\
\text { - Job shadowing } \\
\text { - Mentorship } \\
\text { - Coaching }\end{array}$} \\
\hline Soft Skills & $\begin{array}{l}\text { Communication, critical thinking, creative thinking, } \\
\text { collaboration, adaptability, initiative, leadership, social } \\
\text { emotional learning, teamwork, self-confidence, empathy, } \\
\text { growth mindset, cultural awareness }\end{array}$ & \\
\hline Technical Skills & $\begin{array}{l}\text { Computer programming, coding, project management, } \\
\text { financial management, mechanical functions, scientific } \\
\text { tasks, technology-based skills and other job - specific } \\
\text { skills (e.g., nursing, farming, legal) }\end{array}$ & \\
\hline Entrepreneu & $\begin{array}{l}\text { Initiative, innovation, creativity, industriousness, } \\
\text { resourcefulness, resilience, ingenuity, curiosity, optimism, } \\
\text { risk-taking, courage, business acumen, business execution }\end{array}$ & \\
\hline
\end{tabular}

\section{Lifelong learning}

A continuous process of gaining new knowledge and skills as individuals progress through their professional and personal careers

Source: Deloitte (2018).

Workforce readiness covers the basic skills necessary for employment. Soft skills are "essential human skills," which gain demand with the unfolding 4IR. These include 
personal attributes, social skills, and communication abilities that facilitate interpersonal relations. Soft skills comprise creativity, complex problem-solving, relationship building, communication, emotional intelligence, and critical thinking. Technical skills were defined as knowledge and capabilities to perform specialized tasks. The Fourth Industrial Revolution will create new jobs, also in the fields with a shortage of employees that possess the required technical skills. Industry-specific skills will be in demand, requiring a redefinition of education to training and employment pipeline. Entrepreneurship skills include knowledge and abilities that support success in creating and building a workplace opportunity or idea. The authors of this report highlight that - apart from these four categories of skills - they notice an emphasis on continuous education and lifelong learning, which will help young employees to adapt to the ever-changing landscape of work.

The above results of the study conducted by Deloitte indicate that there are different categories of competency needs that may be categorized both as soft and hard competencies, but similarly to the PwC's survey, the authors do not expose formal vocational qualifications in specific fields.

Moreover, PwC prepared a report for the European Commission which finds that over the last 10 years, there has emerged the term "T-shaped skills," which "refers to an individual worker having a combination of both general skills across multiple domains and specialist skills within one domain" (European Union, 2018). The vertical line of the letter T refers to expert knowledge and experience in a field (the depth of skills), while the horizontal line refers to the skill of collaborating with experts across disciplines and the willingness to use the skills developed during such a collaboration (the breadth of skills). T-shaped skills and competencies are broad in terms of general knowledge and narrow for specialized knowledge. Based on this report, high-tech T-shaped skills are imperative for the EU's competitiveness now and in the future. However, economies such as the EU will experience large skill mismatches, broadened also by 4IR. Therefore, high-tech skills should be accompanied by specific complementary skills which include (European Union, 2018):

- technical skills in an adjacent technology domain or system of thought;

- skills related to quality, risk, and safety;

- management, leadership, and entrepreneurial skills;

- communication skills;

- innovation skills;

- emotional intelligence skills;

- the ability to consider ethical implications of actions. 
T-shaped skills refer to technical competencies in IT and data science, combined with a lifelong learning capacity and potential for reskilling. Such skills should be demonstrated by operators on factory floors, analysts, engineers, and programmers. They will need to think across business models, production processes, machine technology, and data-related procedures (World Economic Forum, 2017). Moreover, the report emphasizes the role of soft and hard competencies in the context of the 4IR.

Therefore, we clearly see that Industry 4.0 requires specific competencies. The same conclusion stems from the conference organized in June 2017 in Poland by the Association of Automotive and Industrial Goods Employers and the Department for Innovation at the Ministry of Economic Development. Future competencies will focus on client needs, meaning that there will be demand for such skills as critical thinking, ability to work in multicultural conditions, openness to digitization, teamwork, complexity, reliability, readiness for change, willingness to change, flexibility, and adaptability to new conditions and environments. Moreover, future competencies will be shaped by the changing surroundings, and there will appear a growing demand for people who are charismatic, good at building relations, curious about the work, open to change, emotionally intelligent, inspirational, kind, responsible, quality-oriented, and digitally agile (PwC, 2017a).

Furthermore, the conference discussed the results of a study conducted on a group of 48 representatives of the automotive industry (car manufacturers and suppliers of car parts and components), which used CATI interviews, an online survey, and individual questionnaires regarding Industry 4.0 and relevant education. The respondents were asked about the readiness of current university graduates for working in Industry 4.0. More than half of respondents (58\%) stated that graduates are not prepared for Industry 4.0 , and only $31 \%$ had a different opinion. The remaining $11 \%$ had no opinion on the matter. The qualifications and skills that should be emphasized for Industry 4.0 include languages (35\% of responses), new technologies/IT solutions (33\%), prioritizing (31\%), teamwork (25\%), time management (25\%), and data analysis (25\%). The biggest barriers in implementing Industry 4.0 - not only for the companies participating in the study but for the whole sector - mainly included the shortage of specialists with relevant qualifications (35\% of respondents) and the lack of sufficient competencies related to new technologies among staff (23\%). Other barriers included uncertainty in terms of the return of investment, data security concerns, costs of adapting to standards for interoperability, and a necessity to change business models (Gros, 2017). The results of these studies may be interpreted as generally emphasizing the importance of soft competencies and some hard competencies. Statements on the shortage of specialists in specific fields may indicate a recognition of the importance of formal vocational qualifications. 
In conclusion, we may ascertain that to evaluate employee competency needs for Industry 4.0, we should use a competency model that covers soft competencies, hard competencies, and formal vocational qualifications in specific disciplines. The results of the above study clearly indicate the importance of soft competencies and the slightly lower importance of hard competencies, while competencies understood as formal vocational qualifications in specific disciplines appeared as having the least significance.

\section{Competency Needs Model for Businesses in Industry 4.0}

In light of the international research and the first studies done in the Polish industry, we may say that there is a significant competency gap among employees regarding Industry 4.0. From the perspective of the possibility of implementing Industry 4.0 in Poland, this gap may soon form a serious barrier to economic development. However, in the long term, breaching this gap will only be possible through education. The speed of industrial changes today is challenging for the companies forced to act both in terms of adjusting technology and implementing relevant changes in terms of the competencies of their employees and managers. The area and scope of changes related to competencies of Polish industrial companies should derive from the maturity of Industry 4.0 in Poland. This means that in order to establish a model of awareness of competency needs in companies, we should refer to the model of digital maturity in Industry 4.0, which was created for supporting Industry 4.0 in Poland.

Figure 2. Model of digital maturity in Industry 4.0
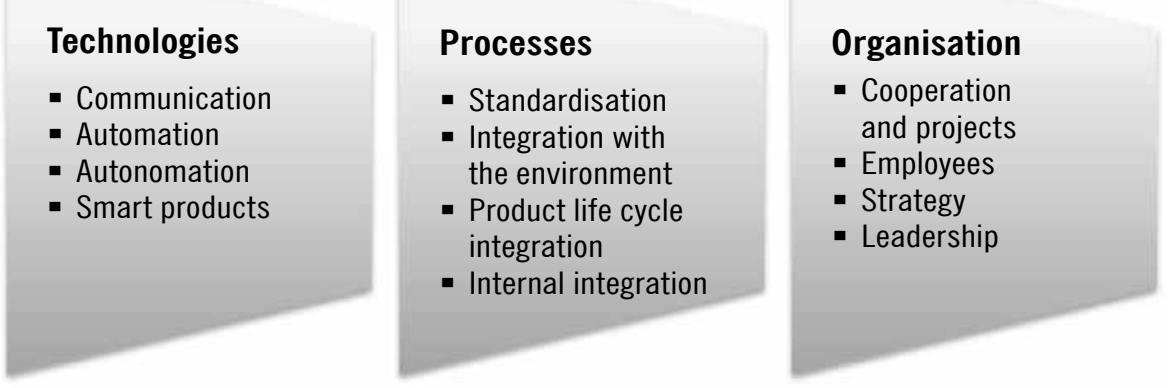

Source: own elaboration of Nosalska et al. (2019).

The model of digital maturity conveys three pillars for developing Industry 4.0 in manufacturing companies. These areas are technologies, processes, and organization (see Figure 2), which determine the utilization of the potential stemming from Indus- 
try 4.0. Apart from these three pillars, the digital maturity model also includes 12 key modules that support the pillars. The modules refer to critical elements on which companies should focus to transform into 4.0 organizations (Nosalska et al., 2019).

The digital maturity model in Industry 4.0 assumes that companies should transform not only in terms of technology and processes but also as organizations, which is determined by the competencies of their employees. Relevant aspects of organizational changes must be accompanied by changes in competency. All modules associated with organization require specific competencies: collaborations, projects, strategy, employees, and leadership. The modules may go in line with corresponding competencies identified based on the above literature review, considering the needs of the employees who form operational teams and of managers. We should emphasize that a separate treatment of managers' competency needs in the 4IR concept has already been identified in the literature (Kannan and Garad, 2020). The model of competency we prepared reflects the aspects of maturity of Industry 4.0 in Polish production companies (see Figure 3).

Figure 3. Model of competency needs in Industry 4.0 companies

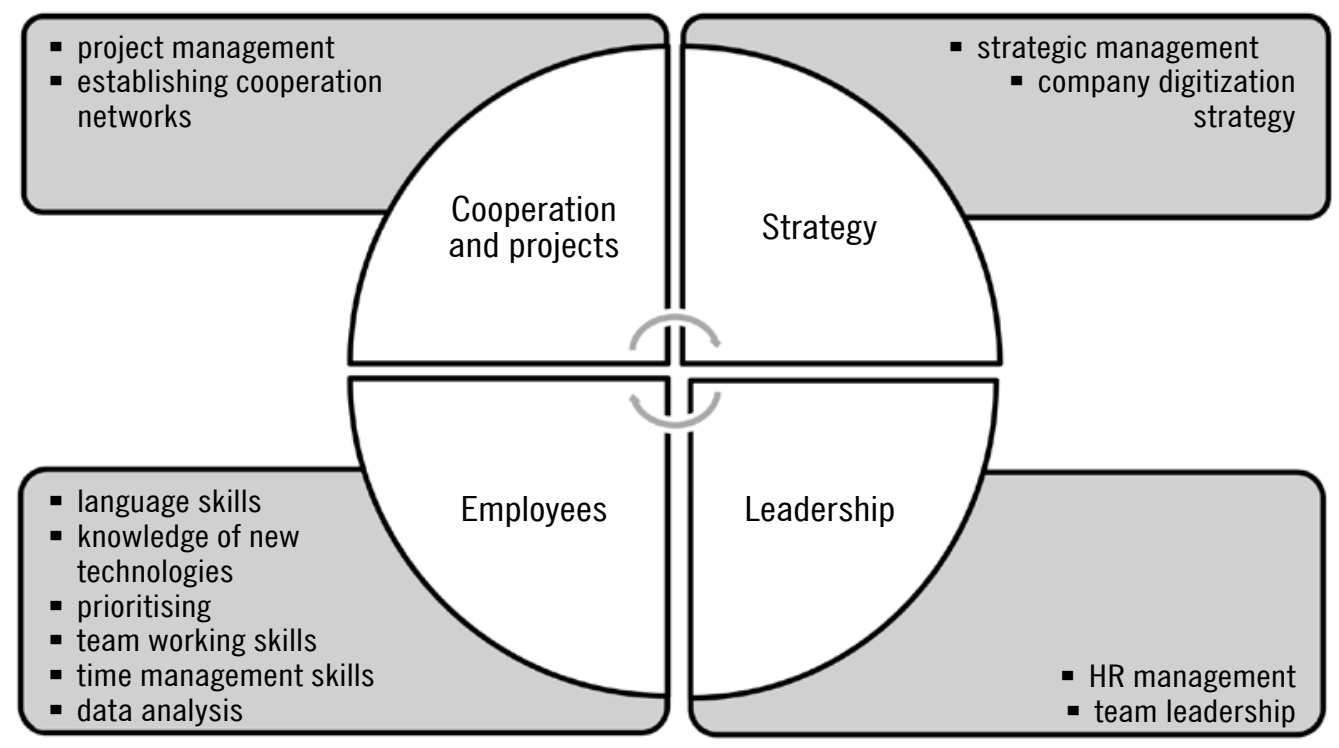

Source: own elaboration of Nosalska et al. (2019). 


\section{Methodology}

The level of awareness of competency needs was also the subject of a wide-scale project entitled "Regional Center for Future Industrial Competency SUPERFACTORY as a Dispersed System." The result of the project was the development of the concept of a Regional Center for Future Industrial Competency as a dispersed cluster-based structure in the platform model. The project also conducted functional tests of the developed concept by implementing existing assets in the region. The project was conducted by the Metal Processing Cluster (Key National Cluster), and it was coordinated by the Center for Promoting Innovation and Development based in Białystok. The project was supported by experts from the University of Białystok (including the authors of this article), Białystok University of Technology, and the companies affiliated with the Metal Processing Cluster (MPC). The project was commissioned by the Ministry of Entrepreneurship and Technology to be carried out from February to March 2019.

The overall objective of the project was to increase the potential of regional businesses by providing them with support in digital transformation by determining the scope of services companies expect in the process, among other things. While the study covered a wide range of services, we will only highlight the services and needs related to the noticeable lack of competencies.

This article raises two research questions. The first research question is "Are competency needs regarding Industry 4.0 noticed by manufacturing companies?” Followed by the hypothesis that:

H1: Manufacturing companies are unaware of all competency needs.

The second research question is: "Can any possible competency needs be satisfied?" Followed by the hypothesis that:

H2: A hypothesis was drawn that competency needs may be satisfied within a network such as a business cooperation network.

Our study was conducted on a group of companies in the metal processing and machinery industry, which is already undergoing advanced transformations due to the unfolding 4IR, as indicated by the experience of companies affiliated with the studied Metal Processing Cluster. 
We analyzed competency needs using two methods. First, a quantitative study was conducted using computer-assisted web interviews (CAWI) among 81 companies in the metal and machine industry in the Podlaskie Voivodeship. Among the studied companies, 67\% were members of the Metal Processing Cluster (MPC). The remaining $33 \%$ were not affiliated with the MPC. The second research method was a qualitative study based on in-depth interviews (IDI) used as an addition to the CAWI study. The goal was to deepen the knowledge about the services related to the Industry 4.0 transformation required by companies. Individual in-depth interviews were conducted in 25 organizations, $48 \%$ of which were businesses, and their responses are presented further in the article. The complementary character of the IDI method became apparent also in the fact that interviews were conducted only on businesses affiliated with the MPC.

The research model assumes that the CAWI method was applied to identify the awareness of new competency needs related to 4IR across the studied companies in terms of their managers and other employees. It was also assumed that the study would do a preliminary evaluation of the companies' readiness to share knowledge with others. Meanwhile, a detailed model of competency needs in Industry 4.0 companies will be verified during in-depth studies using the IDI method, which allows respondents to point out types of competency needs and indicate types of competencies that they could potentially share with others.

\section{Results}

The businesses surveyed using the CAWI method were asked about the types of services that should be offered by the planned Regional Center for Future Industrial Competency. With several options to choose from, the most frequent answer was the one indicating a need for specialized consulting and specialist training services (Figure 4), with $70 \%$ and $56 \%$ responses respectively. These responses may be interpreted to indicate a shortage of competencies among employees of the studied companies. As the Center should provide consultancy and training services, the opinion of the surveyed company representatives was that there are managers and employees potentially interested in using such services, although it must be noted that managers were more interested in specialized consulting, while regular employees wanted specialist training.

In the next part of the study, company representatives were asked specific questions regarding their readiness to use the Center's offer, which was interpreted as the awareness of individual competency needs in their companies. They were also asked about the types of services these companies could offer them as members of the Center. The 
last question asked whether the companies were ready to accommodate for the noticeable lack of competencies in a business cooperation network.

Figure 4. Expectations of the surveyed companies regarding the type of services offered by the Regional Centre for Future Industrial Competence. CAWI surveys

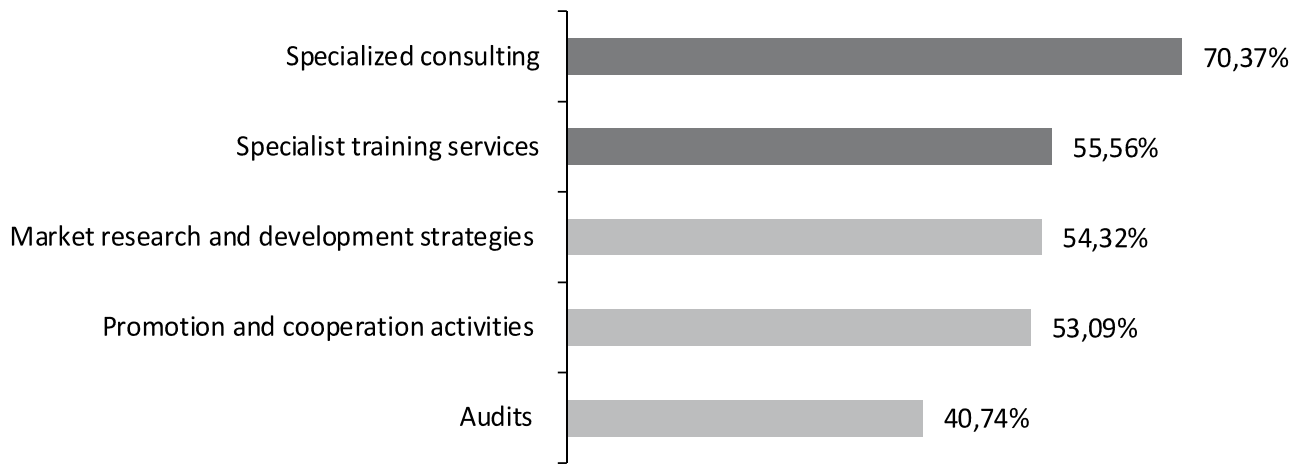

Source: own elaboration based on CAWI surveys conducted within the project Regional Centre for Future Industrial Competence SUPERFACTORY as dispersed system - unpublished report prepared at the request of Ministry of Entrepreneurship and Technology, March 2019.

Figure 5. Competence need awareness among companies and the possibility of satisfying such needs - CAWI results

a) readiness of companies to use the Centre's offer

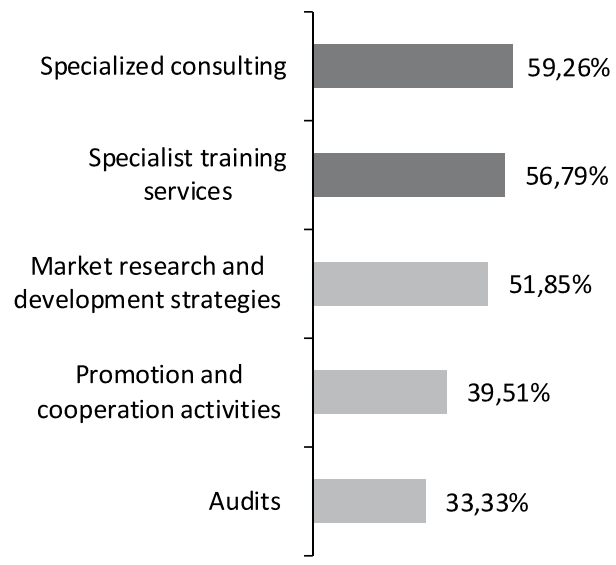

b) services offered by the company within the Centre's network

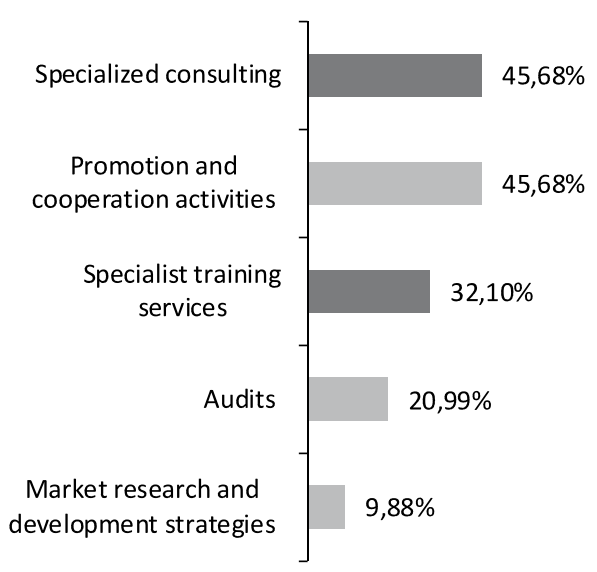

Source: own elaboration based on CAWI surveys conducted within the project Regional Centre for Future Industrial Competence SUPERFACTORY as dispersed system - unpublished report prepared at the request of Ministry of Entrepreneurship and Technology, March 2019. 
In terms of the companies' readiness to use the Center's offer, most responses indicated that the need for specialized consulting and specialist training services (Figure 5a). Specialized consulting was also the number one service when it comes to what the companies had to offer. However, specialist training services ranked number three (Figure 5b). Bearing in mind that the same companies answered both questions, we may say that while companies may offer consulting services, they also are in need of consulting. However, we should stress that the subject of offered and required consulting may be different. Furthermore, there is a specific gap between the offered and required consulting services, which is evident from the fact that $46 \%$ of the companies are willing to offer consulting, while as much as $59 \%$ of businesses need consulting services. There is an even larger gap in terms of access to specialist training services: these are offered by $32 \%$ of the surveyed companies, while $50 \%$ reported demand for such training.

Additional in-depth interviews enabled specifying the types of consulting and forms of training. Moreover, the companies were able to indicate more forms of consulting and training they need in addition to those in the questionnaire. The focus is on consulting and training because these are the two most important forms of increasing competencies.

The first and foremost conclusion from the responses obtained in the IDI study is that companies are more aware of the competency needs among their managers than of the possibility of fulfilling that demand (Figures 6a and 6b). The surveyed companies reported a need for specialized consulting in securing financing, intellectual property protection, patenting, finding partners for projects, getting orders and contracts, and preparing grant applications (over 50\% of responses). Companies show their most significant need for consulting lies in sources of financing, but none of the companies offer such a consultancy in terms of the cooperation network in the Center. However, the study did not provide answers to the question about the reason for such a situation. Nevertheless, we should consider the following: are there no companies in the Center that possess such a knowledge or, rather, companies are unwilling to offer such consulting services despite having such a competency. The first notion is likely false if we consider that while almost $60 \%$ of companies require such consulting, more than $40 \%$ of businesses are either competent in obtaining financing or do not need it; which seems rather unlikely in today's economic climate. Still, the question remains why companies are reluctant to share knowledge about finding sources of financing.

Companies also need services of legal advice, accounting, and investment - albeit to a significantly lesser degree - but none can offer such consulting. The awareness of 
competency needs in terms of intellectual property and patent protection is in similar demand as financing, and only $17 \%$ of companies can provide consulting services on the matter.

Figure 6. Competence need awareness among companies in terms of specialised consulting and the possibility of satisfying such needs - IDI results

a) Competence need awareness regarding:

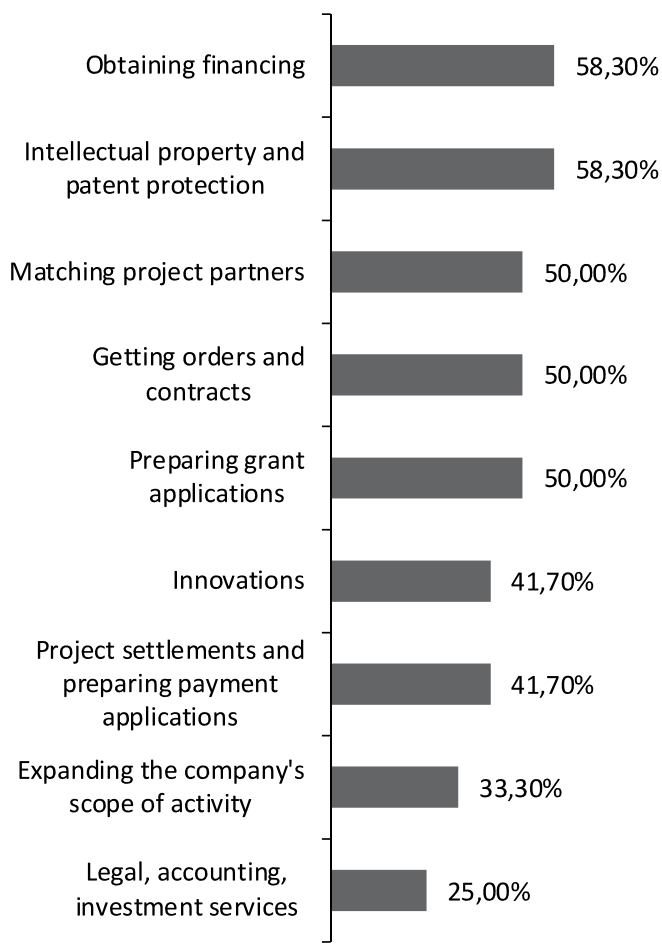

b) Possibility of fulfilling needs within the network in terms of:

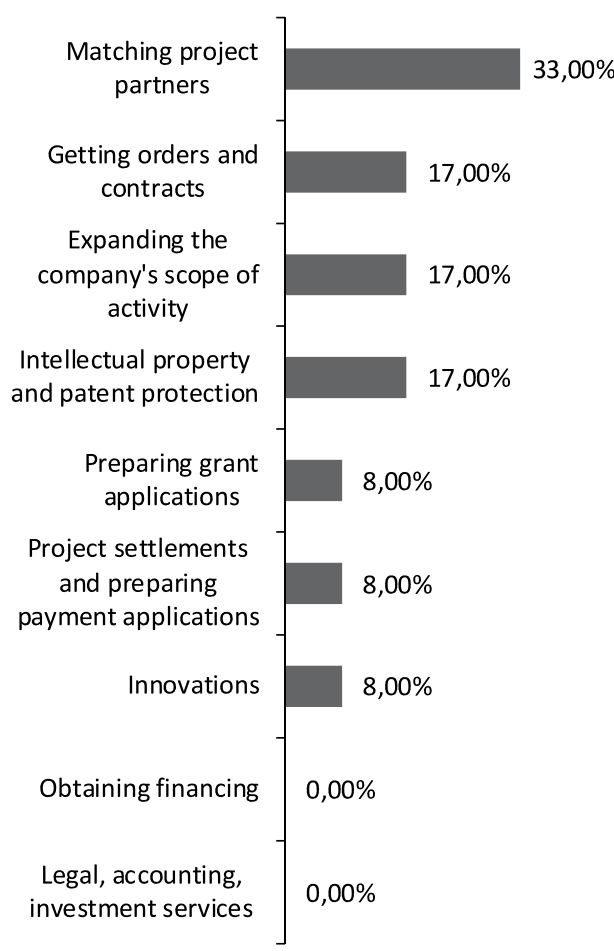

Source: own elaboration based on IDI surveys conducted within the project Regional Centre for Future Industrial Competence SUPERFACTORY as dispersed system - unpublished report prepared at the request of Ministry of Entrepreneurship and Technology, March 2019.

The surveyed companies not only noticed the competency needs of their managers but also of other employees. The competency needs of employees appear clearly regarding specialist training services, especially in terms of training sessions and workshops in managing change and workshops for exchanging experience on new technologies in the organizations. Most of the companies (83.3\%) are interested in the former type of services while not a single business can organize such training. None of the surveyed companies would be able to offer training in modern financial management in future 
industries, while $33 \%$ of companies feel a competency need in this respect. Almost $67 \%$ of companies are interested in experience exchange workshops covering the implementation of new technologies in organizations, and $25 \%$ of companies are willing to offer such services. A similar percentage of companies is willing to organize conferences on new technologies, and as many as $58 \%$ of companies would want to participate (see Table 3).

Table 3. Competency need awareness among companies in terms of specialist training services and the possibility of satisfying such needs - IDI results

\begin{tabular}{|c|c|c|c|}
\hline \multicolumn{2}{|c|}{ Awareness of competency needs } & \multicolumn{2}{|c|}{ Possibility of fulfilling the needs within the network } \\
\hline $\begin{array}{l}\text { Training and workshops on change } \\
\text { management in organisations }\end{array}$ & $83.3 \%$ & $\begin{array}{l}\text { Experience exchange workshops } \\
\text { covering implementation of new } \\
\text { technologies in organisations }\end{array}$ & $25.0 \%$ \\
\hline $\begin{array}{l}\text { Experience exchange workshops } \\
\text { covering implementation of new } \\
\text { technologies in organisations }\end{array}$ & $66.7 \%$ & Conferences on new technologies & $25.0 \%$ \\
\hline Conferences on new technologies & $58.3 \%$ & $\begin{array}{l}\text { Training courses on improving } \\
\text { organisation management efficiency } \\
\text { in a changing environment }\end{array}$ & $16.7 \%$ \\
\hline $\begin{array}{l}\text { Training courses on improving } \\
\text { organisation management } \\
\text { efficiency in a changing } \\
\text { environment }\end{array}$ & $50.0 \%$ & $\begin{array}{l}\text { Conference on change management } \\
\text { in organisations and adapting } \\
\text { organisations to the changing } \\
\text { socio-economic conditions }\end{array}$ & $8.3 \%$ \\
\hline $\begin{array}{l}\text { Experience exchange workshops } \\
\text { on new instruments of managing } \\
\text { organisations' social capital }\end{array}$ & $33.3 \%$ & $\begin{array}{l}\text { Training in modern financial } \\
\text { management in future industries }\end{array}$ & $8.3 \%$ \\
\hline $\begin{array}{l}\text { Training in modern financial } \\
\text { management in future industries }\end{array}$ & $33.3 \%$ & $\begin{array}{l}\text { Experience exchange workshops on new } \\
\text { instruments of managing organisations' } \\
\text { social capital }\end{array}$ & $0.0 \%$ \\
\hline $\begin{array}{l}\text { Conference on change management } \\
\text { in organisations and adapting } \\
\text { organisations to the changing } \\
\text { socio-economic conditions. }\end{array}$ & $25.0 \%$ & $\begin{array}{l}\text { Training and workshops on change } \\
\text { management in organisations }\end{array}$ & $0.0 \%$ \\
\hline
\end{tabular}

Source: own elaboration of IDI surveys conducted for the project Regional Center for Future Industrial Competency SUPERFACTORY as a Dispersed System, an unpublished report prepared requested by the Ministry of Entrepreneurship and Technology, March 2019.

In order to verify the research hypotheses, the results obtained in the survey were confronted with the competency needs model for businesses in Industry 4.0 that we prepared. The first hypothesis was verified by identifying which of the competencies contained in the modules developed within the model are noticed by manufacturing 
companies' representatives. It turns out that the competency need most noticeable among managers refers to cooperation and projects. Managers mainly indicated readiness to use consulting related to financing, matching project partners, preparing grant applications, and settling projects. These results go in line with the steadily increasing demand for professional knowledge on projects and competencies related to project management, with the increase of the significance of projects in business management under Industry 4.0. In the light of these results, managers notice the competency needs of their employees in terms of project management.

\section{Table 4. Verification of hypotheses: a summary}

\begin{tabular}{|l|l|l|l|l|}
\hline \multicolumn{1}{|c|}{ Hypothesis } & $\begin{array}{l}\text { Competencies within the module } \\
\text { Cooperation } \\
\text { and projects }\end{array}$ & Employees & Strategy & Leadership \\
\hline $\begin{array}{l}\text { Awareness } \\
\text { of competency } \\
\text { needs }\end{array}$ & yes & partially yes & yes & no \\
\hline $\begin{array}{l}\text { Possibility } \\
\text { of satisfying } \\
\text { noticed } \\
\text { competency needs }\end{array}$ & no & partially yes & yes & $\begin{array}{l}\text { does not apply } \\
\text { (no noticeable } \\
\text { needs) }\end{array}$ \\
\hline
\end{tabular}

Source: own elaboration of CAWI and IDI surveys conducted for the project Regional Center for Future Industrial Competency SUPERFACTORY as a Dispersed System, an unpublished report prepared requested by the Ministry of Entrepreneurship and Technology, March 2019.

Moreover, managers also notice the needs related to the strategy module, which is demonstrated in their readiness to use consulting on innovation or patent and intellectual property protection. Managers show no competency needs in terms of team leadership or personnel management. Leadership competency did appear among the types of consulting services listed in the questionnaire, and none of the surveyed indicated it in the open question (other). The survey showed that only some of the competency needs of employees are apparent. This mainly concerns the knowledge of new technologies or the ability to manage change in an organization. Accordingly, the first hypothesis proved valid because there are some types of competencies required by Industry 4.0, and whose shortage is felt by the surveyed business representatives.

In order to verify the second hypothesis, the respondents assessed whether the identified competency needs - divided into four modules within the Industry 4.0 competency needs model - can be fulfilled within a network of cooperation of the surveyed companies. It turns out that the most noticeable competency needs of managers - those 
from the cooperation and projects module - cannot be met in the network. The most noticeable competency shortages among other employees - those concerning the management of organizational change - also cannot be fulfilled within the studied network. However, by no means does this mean that it is impossible to meet those needs. To satisfy the needs, we should seek partners beyond the cooperation network: e.g. other companies or institutions in the business environment. The business cooperation network may fulfill the managers' needs from the strategy module as well as other, less perceptible competencies of employees. The second hypothesis is therefore only partially valid.

\section{Conclusions}

This article indicates that the speed of changes in Industry 4.0 makes it necessary for businesses to introduce adaptive changes to technology and other aspects while simultaneously transforming in terms of employee and managerial competencies. In the theoretical part, we proposed a model of competency needs for companies that operate as part of Industry 4.0 in Poland - including the needs of managers and other employees - based on discussions on the nature of competency and the review of studies on competency needs related to Industry 4.0. The model was then used for empirical research that analyzed both the noticeable competency needs related to Industry 4.0 and the potential of the studied companies to share competencies with others. The results of the conducted research verified the hypotheses $\mathrm{H} 1$ and $\mathrm{H} 2$ we formed.

The types of competency needs for Industry 4.0 that have been revealed in the research conducted so far are not fully consistent. Most studies emphasize the importance of hard competencies and formal qualifications. Some studies emphasize the important role of soft skills. Based on our model of digital maturity in Industry 4.0 - which assumes that the transformation to Industry 4.0 requires technological and organizational changes based on our own research results - we conclude that along with the development of Industry 4.0, there appear changes in terms of competency needs. Thus, the research on competency needs concerning entities at different levels of Industry 4.0 implementation unavoidably leads to different conclusions. Interestingly, it seems that as the practice of Industry 4.0 matures, what becomes increasingly important are soft skills. This observation requires further investigation, but it can be justified by the fact that it is easier to educate managers and employees in the field of hard competencies, whereas they can obtain a sufficient level of these competencies relatively quickly. On the other hand, shaping the expected soft skills is a much more difficult process that requires more time. 
The surveyed enterprises undergoing a transformation toward entities 4.0 are aware of the competency needs related to their adaptation to the needs of Industry 4.0. This applies especially to managers in such areas as cooperation and projects, along with strategy. Highlighting the above areas may indicate an early stage of maturing of the surveyed companies to Industry 4.0. Indeed, managers are responsible for making initial decisions and designing new processes and structures, and they require competency support at this initial stage. However, we must stress that at the stage of implementing the new structures, expectations regarding the competencies of other employees will increase as well.

Our survey showed that only some of the competency needs of employees come to the fore. This mainly concerns the knowledge of new technologies or skills related to change management in organizations. It refers to both hard and soft competencies. We conclude that the early stage of shaping Industry 4.0's conditions requires from employees, first of all, specific technical competencies, but also at least one soft competency, which is openness to change. Again, probably with the progress of Industry 4.0 practice, we may expect to gain awareness of a wider set of competency needs in relation to executive employees.

The surveyed enterprises reported both areas of competency needs and the possibility of sharing specific competencies with others. On the one hand, this shows that there is a need to adapt competencies to the needs of Industry 4.0, which is an approach unsatisfactorily offered in the formal education system. This is fully confirmed by the concept of the competency gap of formal education concerning the needs of Industry 4.0 reported in the literature. Enterprises are aware that they need support in some areas, but interestingly, in other areas they have the potential to support others. Such an attitude may result from the fact that we surveyed enterprises mostly belonging to the same cluster. On the other hand, the willingness to share knowledge can be treated as the reason for belonging to a cluster, which is by definition used to share and acquire valuable resources, especially knowledge. In a situation where, based on the numerous cited studies, the formal education system does not keep up with the needs of adjusting competencies to the needs of Industry 4.0. Thus, the concept of the joint development of necessary competencies in a network of enterprises should be assessed very positively, as a natural reaction of enterprises to specific business environment requirements. Many have long since observed that the willingness to cooperate within clusters is largely conditioned by the need to implement innovations in specific sectors (Grashof, Hesse, and Fornahl, 2019; Kuksa et al., 2019). Therefore, at the initial stage of the development of Industry 4.0 - at least in medium-developed countries such as Poland - we may expect that there will be an increased willingness of enterprises to cooperate. 
This conclusion goes beyond the adopted research area, thus constituting an interesting direction for future research.

Generally, when comparing the level of already expected support in the field of building competencies for Industry 4.0 and the support that can be provided by the mutually examined enterprises, a significant gap appears that should be filled through the activity of external institutions, possibly with public support. If public authorities care about the effective transformation of the economy into Industry 4.0, it is reasonable to use programs that support the competencies of employees in terms of new requirements. The forms of such support should only be identified and assessed in the course of further research. Therefore, we conclude that the failure to meet the competency needs of enterprises transforming to Industry 4.0 may constitute a significant barrier to the expected transformation of enterprises.

The reported study was of a pilot nature, and the created competency model will be further studied and continued in order to be verified on a larger sample of companies. This is a necessary course of action that will consider the processes related to 4IR. The processes may contribute to the introduction of new competency needs in companies, which will then have to be included in the model. The above-presented study is worthy of further exploration directed at specifying behavioral competency gaps related to Industry 4.0 that could be identified in managers and other employees. Another line of future research should consider the possibility of filling behavioral competency gaps by using formal education systems and lifelong education, along with internships and apprenticeships.

Our study revealed the importance of behavioral competencies for both managers and other employees. Despite being a pilot study with a limited sample, it confirmed that the competencies of managers and other employees are one of the key conditions for implementing the Industry 4.0 concept in Poland.

\section{References}

Armstrong, M. (2002). Zarzq̨dzanie zasobami ludzkimi. Kraków: Oficyna Ekonomiczna.

Armstrong, M., and Taylor, S. (2014). Armstrong's Handbook of Human Resource Management Practice. 13th Edition. London: Kogan Page.

Azmat, F., Ahmed, B., Colombo, W., and Harrison, R. (2020). Closing the Skills Gap in the Era of Industrial Digitalisation. In: 2020 IEEE Conference on Industrial Cyberphysical Systems (ICPS) (pp. 365-370). Tampere: IEEE. https://doi.org/10.1109/ICPS48405.2020.9274788.

Blayone, T.J.B., and Van Oostveen, R. (2021). Prepared for work in Industry 4.0? Modelling the target activity system and five dimensions of worker readiness. International Journal of Computer Integrated Manufacturing, 34(1), 1-19. https://doi.org/10.1080/0951192X.2020.1836677. 
Borkowska, S. (2001). Strategie wynagrodzeń. Kraków: Oficyna Ekonomiczna.

Boyatzis, R. (1982). The Competent Manager: A model for effective performance. New York: Wiley.

Deloitte (2018). Preparing tomorrow's workforce for the Fourth Industrial Revolution For business: A framework for action. Obtained from: http://przemysl-40.pl/wp-content/uploads/2018-DeloitteGBC-Brochure.pdf (access: 18.11.2019).

Dhanpat, N., Buthelezi, Z.P., Joe, M.R., Maphela, T.V., and Shongwe, N. (2020). Industry 4.0: The role of human resource professionals. SA Journal of Human Resource Management/SA Tydskrif vir Menslikehulpbronbestuur, 18(0). https://doi.org/10.4102/sajhrm.v18i0.1302.

Dubois, D.D., and Rothwell, W.J. (2008). Zarzqdzanie zasobami ludzkimi oparte na kompetencjach. Gliwice: Helion.

Dumitrescu, A., Lima, R.,Chattinnawat, W., and Savu, T. (2019). Industry 4.0 competencies' gap analysis. International Scientific Journals Industry 4.0, 4(3), 138-141.

European Union (2018). Skills for Smart Industrial Specialisation and Digital Transformation Interim Report. Luxembourg: Publications Office of the European Union.

Filipowicz, G. (2016). Zarzqdzanie kompetencjami. Perspektywa firmowa i osobista. Warszawa: Wolters Kluwer Polska.

Gick, A., and Tarczyńska, M. (1999). Motywowanie pracowników. Warszawa: PWE.

Grashof, N., Hesse, K., and Fornahl, D. (2019). Radical or not? The role of clusters in the emergence of radical innovations. European Planning Studies, 27(10), 1904-1923.

https://doi.org/10.1080/09654313.2019.1631260.

Gros, P. (2017). Przemysł 4.0 i edukacja. Opinie przedstawicieli branży motoryzacyjnej, wyzwania rozwiqzania. Obtained from: http://przemysl-40.pl/wp-content/uploads/2017/07/konferencja_ MR_2017_3.pdf (access: 18.11.2019).

Halse, L.L., and Jaeger, B. (2019). Operationalizing Industry 4.0: Understanding Barriers of Industry 4.0 and Circular Economy. In: F. Ameri, K.E. Stecke, G. von Cieminski, and D. Kiritsis (eds.), Advances in Production Management Systems. Towards Smart Production Management Systems (Vol. 2, pp. 135-142). Austin: Springers. https://doi.org/10.1007/978-3-030-29996-5_16.

Innogy Polska SA (2019). Megatrendy zmieniajace przemysł. Polskie firmy produkcyjne na tle globalnych megatrendów przemysłowych. Obtained from: https://przemysl-40.pl/wp-content/ uploads/2019-innogy.pdf 4-8 (access 18.11.2019).

Imran, F. and Kantola, J. (2019). Review of Industry 4.0 in the Light of Sociotechnical System Theory and Competence-Based View: A Future Research Agenda for the Evolute Approach. In: J.I. Kantola, S. Nazir, and T. Barath (eds.), Advances in Human Factors, Business Management and Society, Proceedings of the AHFE 2018 International Conference on Human Factors, Business Management and Society (pp. 118-128). Orlando: Springers. https://doi.org/10.1007/978-3-319-94709-9_12.

Kannan, K.S.P.N., and Garad, A. (2021). Competencies of quality professionals in the era of industry 4.0: a case study of electronics manufacturer from Malaysia. International Journal of Quality $\&$ Reliability Management, 38(3), 839-871. https://doi.org/10.1108/IJQRM-04-2019-0124.

Khan, N., Khan, S., Tan, B.C., and Loon, C.H. (2021). Driving Digital Competency Model towards IR 4.0 in Malaysia. Journal of Physics: Conference, The 1st International Recent Trends in Technology, Engineering and Computing Conference (IRTTEC), 1793 (012049).

https://doi.org/10.1088/1742-6596/1793/1/012049.

Król, H., and Ludwiczyński A. (2014). Zarzqdzanie zasobami ludzkimi. Warszawa: Wydawnictwo Naukowe PWN.

Kuksa, I., Shtuler, I., Orlova-Kurilova, O., Hnatenko, I., and Rubezhanska, V. (2019). Innovation Cluster as a Mechanism for Ensuring The Enterprises Interaction In The Innovation Sphere. 
Management Theory and Studies for Rural Business and Infrastructure Development, 41(4), 487-500. https://doi.org/10.15544/mts.2019.39.

Made Sudana, I., Apriyani D., and Nurmasitah, S. (2019). Revitalization of vocational high school roadmap to encounter the 4.0 industrial revolution. Journal of Social Sciences Research, 5(2), 338-342.

McClleland, D.C. (1973). Testing for Competence Rather Than for "Intelligence”. American Psychologist, $28,13$.

Hernandez-de-Menendez, M., Morales-Menendez, R., Escobar, C.A., and McGovern, M. (2020). Competencies for Industry 4.0. International Journal on Interactive Design and Manufacturing, 4, 1511-1524. https://doi.org/10.1007/s12008-020-00716-2.

Nosalska, K., Śledziewska, K., Włoch, R., and Gracel, J. (2019). Wsparcie dla przemysłu 4.0 w Polsce. Prototyp narzędzia oceny dojrzałości cyfrowej przedsiębiorstw produkcyjnych. Warszawa: DELab UW.

PwC (2017). 20th CEO Survey, 20 years inside the mind of the CEO... What's next? Obtained from: https://www.pwc.com/gx/en/ceo-survey/2017/pwc-ceo-20th-survey-report-2017.pdf (access: 18.11.2019).

PwC (2017a). Pracownik 4.0, czyli jakich kompetencji wymagaja ciqgłe zmiany? Obtained from: http://przemysl-40.pl/wp-content/uploads/2017/07/konferencja_MR_2017_4.pdf (access 18.11.2019).

Rawboon K., Yamazaki, A.K., Klomklieng, W., and Thanomsub, W. (2021). Future competencies for three demanding careers of industry 4.0: Robotics engineers, data scientists, and food designers. The Journal of Competency-based Education, 6. https://doi.org/10.1002/cbe2.1253.

Ribeiroa, A., Amaralb, A., and Barrosb, T. (2021). Project Manager Competencies in the context of the Industry 4.0. Procedia Computer Science, 181, 803-810.

Regional Center for Future Industrial Competency SUPERFACTORY as a Dispersed System, an unpublished report prepared requested by the Ministry of Entrepreneurship and Technology.

Sajkiewicz, A. (2002). Kultura, kompetencje, konkurencyjność. Warszawa: Poltext.

Terkowsky, C., Frye, S., and May, D. (2019). Is a Remote Laboratory a Means to Develop Competences for the 'Working World 4.0'? A Brief Tentative Reality Check of Learning Objectives. In: 2019 5th Experiment International Conference. Funchal: IEEE.

https://doi.org/10.1109/EXPAT.2019.8876532.

Tūtlys, V., and Spöttl, G. (2021). Disruption of qualifications in manufacturing: challenges and prospects. European Journal of Training and Development, ahead-of-print.

https://doi.org/10.1108/EJTD-07-2020-0121.

Welch, J., and Byrne, J.A. (2003). Jack: Straight from the Gut. Business Plus. Grand Central Publishing. Wichmann, R.L., Eisenbart, B., and Gericke, K. (2019). The Direction of Industry: A Literature Review on Industry 4.0. In: Proceedings of the 22nd International Conference on Engineering Design (ICED19). Delft, The Netherlands, 5-8 August 2019. https://doi.org/10.1017/dsi.2019.219.

World Economic Forum (2017). Technology and Innovation for the Future of Production: Accelerating Value Creation, White Paper, Geneva, 21.

Authors'participation in the project Regional Center for Future Industrial Competence SUPERFACTORY as dispersed system - unpublished report prepared at the request of Ministry of Entrepreneurship and Technology, March 2019. 